\title{
Lesser-known ethnic leafy vegetables Talinum paniculatum grown at tropical ecosystem: Morphological traits and non-destructive estimation of total leaf area per branch
}

\author{
BENYAMIN LAKITAN ${ }^{1,2,}$, KARTIKA KARTIKA $^{3}$, LAILY ILMAN WIDURI ${ }^{4}$, ERNA SIAGA $^{5}$, \\ LYA NAILATUL FADILAH ${ }^{1}$ \\ ${ }^{1}$ Faculty of Agriculture, Universitas Sriwijaya. Jl. Raya Palembang-Prabumulih Km 32, Indralaya, Ogan Ilir 30662, South Sumatra, Indonesia. \\ Tel./fax.: +62-711-580276, `email: blakitan60@unsri.ac.id \\ ${ }^{2}$ Research Center for Sub-optimal Lands, Universitas Sriwijaya. Jl. Padang Selasa No. 524, Bukit Besar, Palembang 30139, South Sumatra, Indonesia \\ ${ }^{3}$ Research Center for Biology, Research Organization for Life Sciences, National Research and Innovation Agency. Jl. Raya Jakarta-Bogor Km. 46, \\ Cibinong, Bogor 16911, West Java, Indonesia \\ ${ }^{4}$ Faculty of Agriculture, Universitas Jember. Kampus Bumi Tegal Boto, Jl. Kalimantan No. 37, Jember 68121, East Java, Indonesia \\ ${ }^{5}$ Faculty of Agriculture, Universitas Bina Insan. J1. H.M. Soeharto, Lubuklinggau 31626, South Sumatra, Indonesia
}

Manuscript received: 2 September 2021. Revision accepted: 26 September 2021.

\begin{abstract}
Lakitan B, Kartika K, Widuri LI, Siaga E, Fadilah LN. 2021. Lesser-known ethnic leafy vegetables Talinum paniculatum grown at tropical ecosystem: Morphological traits and non-destructive estimation of total leaf area per branch. Biodiversitas 22: 44874495. Talinum paniculatum known as Java ginseng is an ethnic vegetable in Indonesia that has also been utilized as a medical plant. Young leaves are the primary economic part of $T$. paniculatum, which can be eaten fresh or cooked. This study was focused on characterizing morphological traits of $T$. panicultaum and developing a non-destructive yet accurate and reliable model for predicting total area per leaf cluster on each elongated branch per flush growth cycle. The non-destructive approach allows frequent and timely measurements. In addition, the developed model can be used as guidance for deciding the time to harvest for optimum yield. Results indicated that $T$. paniculatum flourished rapidly under wet tropical conditions, especially if they were propagated using stem cuttings. The plants produced more than 50 branches and more than 800 leaves, or on average produced more than 15 leaves per branch at the age of nine weeks after planting (WAP). The zero-intercept linear model using a combination of two traits of length $\mathrm{x}$ width (LW) as a predictor was accurate and reliable for predicting a single leaf area $\left(\mathrm{R}^{2}=0.997\right)$. Meanwhile, the estimation of total area per leaf cluster was more accurate if three traits, i.e., number of leaves, the longest leaf, and the widest leaf in each cluster were used as predictors with the zero-intercept linear regression model $\left(\mathrm{R}^{2}=0.984\right)$. However, the use of a single trait of length $(\mathrm{L})$ and width $(\mathrm{W})$ of the largest leaf within each cluster as a predictor in the power regression model exhibited moderately accurate prediction at the $\mathrm{R}^{2}=0.883$ and 0.724 , respectively.
\end{abstract}

Keywords: Ethnic plant, flush growth, leaf area prediction, leaf cluster, traditional medicine, zero intercept regression

Abbreviations: L: leaf length; LA: leaf area; LFW: leaf fresh weight; LW: rectangular of length $\mathrm{x}$ width; NoL: number of leaves; W: leaf width; WAP: week after planting

\section{INTRODUCTION}

The shoot of Talinum paniculatum (Jacq.) Gaertn. is morphologically different from Korean ginseng (Panax ginseng C.A.Mey), but their enlarged roots look similar. Roots of T. paniculatum exhibited high similarity with roots of $P$. ginseng and it was almost impossible to differentiate among them (Osathanunkul \& Madesis 2019). However, T. paniculatum has not been reported to contain the active compounds of ginsenosides in its roots. Therefore, most studies on $T$. paniculatum have been focused on its health benefits as a medicinal plant.

Talinum paniculatum is also known as Java ginseng (Arefin et al. 2021), som Jawa (Saribanon et al. 2021), kolesom (Kusumadewi et al. 2011), Thai ginseng (Osathanunkul \& Madesis 2019), Major Gomes or Erva Gorda plants (Moura et al. 2021; Tolouei et al. 2019), jewels of opar (Nguyen et al. 2018), and many more local names. In Indonesia, T. paniculatum is also considered an ethnic leafy vegetable. At present, it is not widely consumed as a vegetable in Indonesia and, most likely, also not by the global community. In many countries, $T$. paniculatum is classified as a minor or ethnic vegetable (Moura et al. 2021), or in some cases, it is treated as a weed. The edible parts of T. paniculatum are stems, leaves, and roots, which are rich in protein, amino acids, zinc, and iron (Moura et al. 2021).

The young leaf of $T$. paniculatum is the palatable primary part. It can be eaten fresh or cooked. The leaf is semi-succulent with a thickness of less than $1 \mathrm{~mm}$. The canopy architecture of $T$. paniculatum has not been scientifically studied. The early observation indicated that the canopy was developed by periodical (about every two weeks) flush growth of 3 long branches ended with a cluster of packed leaves (about 10-20 leaves) and terminated with inflorescence. Cutting the peduncle of the inflorescences before the first flower bloom triggers the next flush growth. It is possible to repeat this cycle several 
times to maximize leaf yield. Each $T$. paniculatum plant produces hundreds of leaves. Therefore, a model is needed for accurately predicting the total area of all leaves per cluster on each branch.

Considering leaf as the primary economic part of $T$. paniculatum as a promising vegetable, this study's objective is to develop a non-destructive yet accurate and reliable model for predicting the total area per leaf cluster on each elongated leaf branch per flush growth cycle. Leaf area is directly related to leaf fresh weight. The nondestructive approach allows for frequent and timeflexibility for measurements such that the model can be used as guidance for deciding the time to harvest for optimum yield on fresh leaf weight.

\section{MATERIALS AND METHODS}

\section{Biomaterial used and cultivational procedures}

Seeds of $T$. paniculatum were collected from a single mother plant to maximize the homogeneity of samples used in this study. Morphological characteristics of the mother plant are shown in Figure 1. Two different planting materials were compared, i.e., seeds and stem cuttings. The seeds were directly broadcasted on moist soil's flat surface and exposed to sunlight directly. Soil moisture was maintained by spraying the soil surface with fine water droplets at low pressure. The seedlings were transplanted into pots containing soil-manure mixed substrate. Plot size was $30 \mathrm{~cm}$ in diameter and $30 \mathrm{~cm}$ in height, filled with the substrate up to $25 \mathrm{~cm}$ in height. The length of stem cutting was $10 \mathrm{~cm}$. Planted to a depth of $5 \mathrm{~cm}$ in a similar substrate and pot size. The plants were maintained with regular watering, and NPK fertilizer was applied three weeks after planting, both for seedlings and stem cuttings.

The canopy architecture of $T$. paniculatum was relatively predictable. At the end of the main stem, the flush growth occurred developed three first branches, yet some smaller branches also developed along the main stem. The second flush growth developed the next three-second branches occurred at the junction between the end of each first branch and the base of its peduncle. Just below the junction or near the upper end of the first branch, there was a cluster consisted of 10 to 20 leaves. Repeated flush growths followed a similar pattern that normally occurred until the development of the fourth branches (Figure 2). After the first branches, the next branches and leaves size became continuously smaller. The number of leaves on each branch also continuously decreased to about 6-8 smaller leaves.

\section{The needs for leaf area estimation model}

The total number of leaves per plant reached more than 450 leaves. The surface area of the fully-expanded leaf in T. paniculatum varied from less than $1 \mathrm{~cm}^{2}$ to more than 85 $\mathrm{cm}^{2}$. Even if the measurement of area for each of 450 leaves with varying sizes is conducted destructively using a sophisticated leaf area meter, it still takes considerable time. It is more so if measurements require non-destructive and are frequently taken during the stretch of plant growth and development. Therefore, leaf area estimation models should be a viable solution for shortening the time, simplifying the procedure, and satisfying the need for nondestructive measurement.

The selected models should be fallen into these criteria: (a) selected predictor(s) can be measured non-destructively, (b) predictor should be a morphological trait or traits that directly related to leaf, and (c) the model has been proven to accurately estimate total area of all leaves per branch, although there was variation in individual leaf size and the number of leaf per cluster.

\section{Data collection}

More than 600 leaves were selected and measured, but only 591 leaves were used in developing the models due to probable errors during data entry. Data were eliminated if measured leaf area (LA) was larger than a multiplication of leaf length (L) and width (W), abbreviated as LW or if measured LA was higher or lower than predicted LA plus or minus twice of the standard deviation $\left(\mathrm{R}^{2}\right)$. Nondestructively measured data on 591 leaves were L, W, leaf thickness, and the number of leaves (NoL) per cluster. Destructive measurement data specifically for model development were leaf fresh weight (LFW) and leaf area (LA). The longest and widest leaves within each leaf cluster were identified at post-data collection based on the available database. Leaf thickness was measured using a digital caliper (Type SH20, Taffware Co., Indonesia), and LA was measured using an automated digital image analysis application (Easlon and Bloom 2014).

\section{Model development}

There are two major tasks in developing a leaf area estimation model, i.e., selecting relevant predictor(s) and the most accurate and reliable regression model to be adopted. In this study, the challenge was increased further by using morphological traits at individual leaf levels to estimate leaf clusters' total area on each branch of $T$. paniculatum. Conventional allometric predictors and types of regressions that have been proven to be reliable (Lakitan et al. 2017; 2018; 2021; Meihana et al. 2017; Widuri et al. 2017) were adopted, but an additional trait was acquired for increasing the accuracy of LA estimation model, i.e., number of lobes (NoL).

\section{Statistical analysis}

Power regression was adopted as a basic leaf area estimation model since it nicely fit most of the probable predictors amongst plant morphological traits, i.e., $\mathrm{LA}=\mathrm{a}$ $\mathrm{L}^{\mathrm{b}}$ or $\mathrm{LA}=\mathrm{a} \mathrm{W}^{\mathrm{b}} ; \mathrm{a}$ and $\mathrm{b}$ are the coefficients that describe the relationship between $\mathrm{L}$ and LA or W and LA, respectively. However, in this study, the zero-intercept linear regression was used as an alternative if two or more traits were combined and used as a predictor, i.e., $\mathrm{LA}=\beta$ $\mathrm{LW}$ and $\mathrm{LA}=\beta \mathrm{LW}^{*} \mathrm{NoL}$, and the zero-intercept quadratic regression was used if single traits of $\mathrm{L}$ or $\mathrm{W}$ were separately used as a predictor, i.e., $\mathrm{LA}=\beta \mathrm{L}+\delta \mathrm{L}^{2}$ or $\mathrm{LA}$ $=\beta \mathrm{W}+\delta \mathrm{W}^{2}$. The coefficient of determination $\left(\mathrm{R}^{2}\right)$ indicates the accuracy level of each developed model. The $\mathrm{R}^{2}$ value between measured and predicted LA indicates the reliability of the model. 

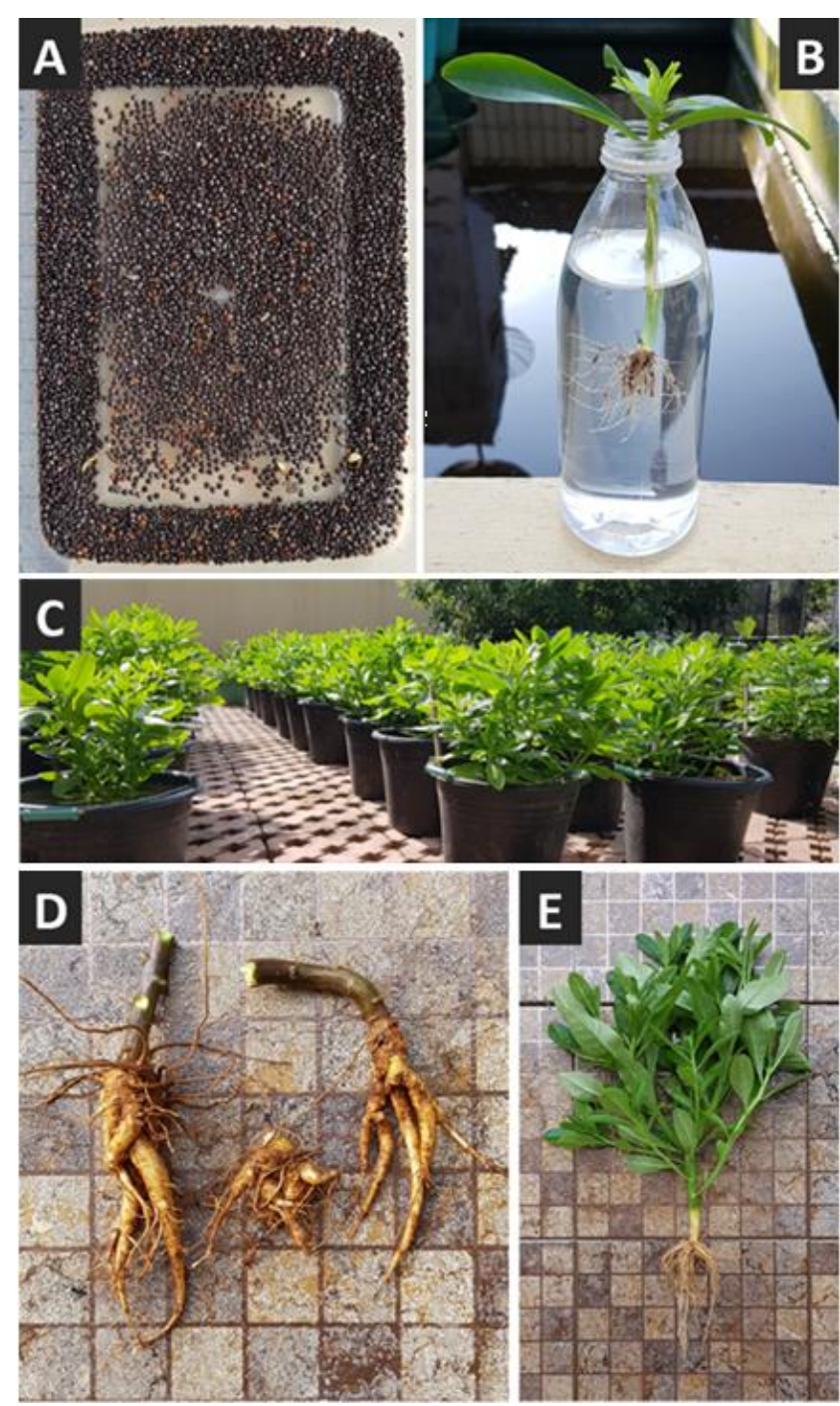

Figure 1. A. Morphological characteristics of Talinum paniculatum Mature seeds ready for cultivation; B. Roots development at one week after stem cutting was planted; C. Relatively uniform plants at five weeks after planting using stem cuttings; D. Roots of matured plants grown from seeds; E. Smaller roots in a plant grown using stem cuttings

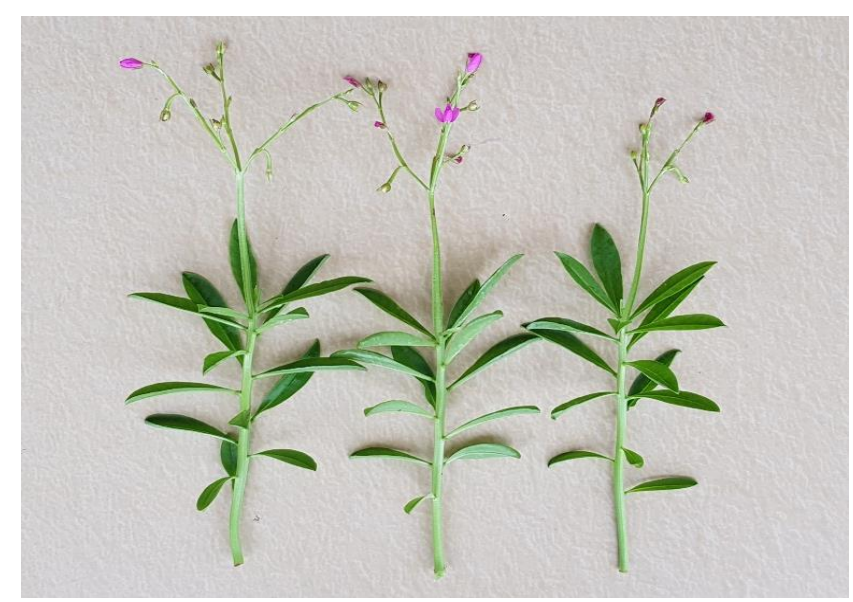

Figure 2. Flush growth of second branches, showing leaf cluster and inflorescence on each branch of Talinum paniculatum

\section{RESULTS AND DISCUSSION}

\section{The rapid growth of Talinum paniculatum}

Talinum paniculatum grew rapidly under wet tropical conditions, especially if they were grown using stem cuttings. The plant produced almost 30 branches and more than 300 leaves, or on average, produced more than ten leaves per branch at the age of five weeks after planting (WAP). Further, at nine WAP, the branches increased about $90 \%$, leaves about $155 \%$, and average leaf/branch more than $33 \%$ (Table 1). Number of branches (NoB), number of leaves (NoL), and average number of leaves per branch are yield-related traits in leafy vegetables. The number of branches and leaves of $T$. paniculatum in this study was higher than the reported results of Purbajanti et al. (2019), which revealed the increase of the number of branches within four weeks was $50 \%$, with the maximum number of leaves per plant of 179. In addition, the growth of $T$. paniculatum is also affected by the sufficient availability of soil nutrients, soil texture, and water availability (Samuel et al. 2017; Oluwole et al. 2018).

\section{Response of Talinum paniculatum to NPK fertilizer}

As a leafy vegetable, $T$. paniculatum was best harvested at seven to nine WAP. Frequent shoot harvesting retained the plant at the vegetative stage (Saleh et al. 2014). After nine WAP, the third branches started to develop inflorescence at each of its apexes. Earlier harvest at six WAP is also possible if NPK fertilizer is applied at $5 \mathrm{~g}$ per plant. Talinum paniculatum exhibited a significant positive response to NPK application (Figure 3).

Application of NPK increased SPAD value in $T$. paniculatum gradually. Higher SPAD value indicated high chlorophyll content and $\mathrm{N}$ concentration in leaf (Nyi et al. 2012). Uko et al. (2019) observed a wider leaf surface, profuse branches, and higher leaf area index as a result of a higher photosynthetic rate after the application of poultry manure containing high NPK.

The plants might be maintained for a longer period if the cultivation is mainly for producing larger roots. In this case, early pinching of all developed inflorescences is necessary. Removal of inflorescences resulted in translocation of photosynthates exclusively to the vegetative organs, including roots, stems, and leaves. Sunday and Chukwuka (2016) recommended a weekly inflorescence removal in order to obtain an optimum yield of $T$. triangulare. Proctor et al. (2011) reported that inflorescence removal increased $26 \%$ of root yield and 38.6 $\%$ of leaf fresh weight in American ginseng.

Table 1. Number of branches, leaves, and ratio of leaf/branch at five and nine weeks after planting

\begin{tabular}{lcc}
\hline \multirow{2}{*}{ Traits } & \multicolumn{2}{c}{ Plant age (weeks after planting) } \\
\cline { 2 - 3 } & 5 WAP & 9 WAP \\
\hline Branch/plant & $29.2 \pm 1.88 \mathrm{a}$ & $55.6 \pm 2.80 \mathrm{~b}$ \\
Leaf/plant & $318.3 \pm 21.2 \mathrm{a}$ & $812.3 \pm 36.0 \mathrm{~b}$ \\
Leaf/branch & $11.1 \pm 0.51 \mathrm{a}$ & $14.8 \pm 0.58 \mathrm{~b}$ \\
\hline
\end{tabular}

Note: Numbers represent mean \pm standard error. Different small letters on each row indicated a significant increase in each measured trait 
Plants with a large number of leaves, such as $T$. paniculatum, cause measurement of canopy area based on image analysis becomes meaningless due to high degree of overlapping amongst existing leaves, i.e., plants with a similar value of canopy area may have significantly different in total leaf area. However, measuring each of the leaves at a large number is very laborious, consumes valuable research time, and may decrease the accuracy of measurements.

\section{Propagation of Talinum paniculatum using stem cuttings}

Results of the present study did not show a significantly different effect between straight and slanting cuts on the canopy area of $T$. paniculatum. Leaves of $T$. paniculatum are sessile, they do not have a petiole. Therefore, the leaves' blades are densely packed within leaf clusters on each branch, creating overlapping amongst leaves' blades since early vegetative growth. Plants grown using stem cutting with 5 and 10 leaves exhibited faster growth and a higher canopy area than plants grown with leaf-less stem cutting. It shows the importance of leaves as sources of photosynthate for successful rooting of the cuttings. Retaining some leaves improved the rooting success rate and formation of adventitious roots in cuttings (Caplan et al. 2018). The plant growth rate is indicated by the higher number of leaves and larger canopy area. Insignificant differences in canopy area measured at three WAP between plants initially grown using stem cutting with 5 and 10 leaves were revealed that overlapping amongst leaf blades had occurred at the early vegetative stage (Figure 4). This finding leads to the need for developing a non-destructive measurement of the total leaf area of $T$. paniculatum.

\section{Predicting of single leaf area and total area per leaf cluster}

Pezzini et al. (2018) agreed that a single-trait predictor $(\mathrm{L}$ or $\mathrm{W})$ required less labor than the use of two traits (LW). Toebe et al. (2019) reported that W was better than L for LA estimation in squash. Misgana et al. (2018) preferred to use two traits for higher accuracy although it required more time on $\mathrm{L}$ and $\mathrm{W}$ measurements. Teobaldelli et al. (2019) moderately suggested choosing the model according to its main purpose, i.e., for quick comparison or use as an estimation model.

Single-trait and two-trait predictors were selected to develop the LA estimation model in T. paniculatum (Figure 5 ). The $\mathrm{R}^{2}$ value was calculated to examine the accuracy of the model using the zero-intercept quadratic model (dashed line) and power regression model (dotted line). Single-trait predictor using $\mathrm{L}$ and $\mathrm{W}$ on both models resulted in a high $\mathrm{R}^{2}$ value $\left(\mathrm{R}^{2}>0.97\right)$. However, high reliability was found in the power regression model using a combination of two traits (LW) as a predictor as well as in the zero-intercept linear model. LA estimation models using a single trait of $\mathrm{L}$ or $\mathrm{W}$ were preferable for saving a working hour or if a large number of leaf samples were used; however, $L A=\beta$ LW model is recommended for maximizing accuracy $\left(\mathrm{R}^{2}=\right.$ 0.9968) in estimating LA of $T$. paniculatum.

The accuracy of leaf dimensional traits as a predictor was also tested using two models, the zero-intercept quadratic and the power model (Figure 6). Leaf thickness as a predictor was less suitable on both models with $\mathrm{R}^{2}$ values of 0.5144 and 0.4953 , respectively. Lower reliability of LA estimation using this predictor was related to inconsistency between leaf thickness and leaf size in $T$. paniculatum. Despite the actual leaf growth is threedimensional, in some cases, leaf thickness increment was considered negligible during leaf development, compared to $\mathrm{L}$ and $\mathrm{W}$. Geometrical principle as explained by Lakitan et al. (2017) endorsed LW as a relevant predictor for reliably predicting LA. Non-dimensional traits of leaf fresh weight were also examined as a predictor. Two regression models were used to compare the most accurate model. Both zero intercept linear and power regression showed high $\mathrm{R}^{2}$ with the values of 0.9518 and 0.9755 , respectively. However, a destructive measurement is needed for collecting fresh leaf weight data, which hinders the possibility of performing a sequential measurement on the same leaf.

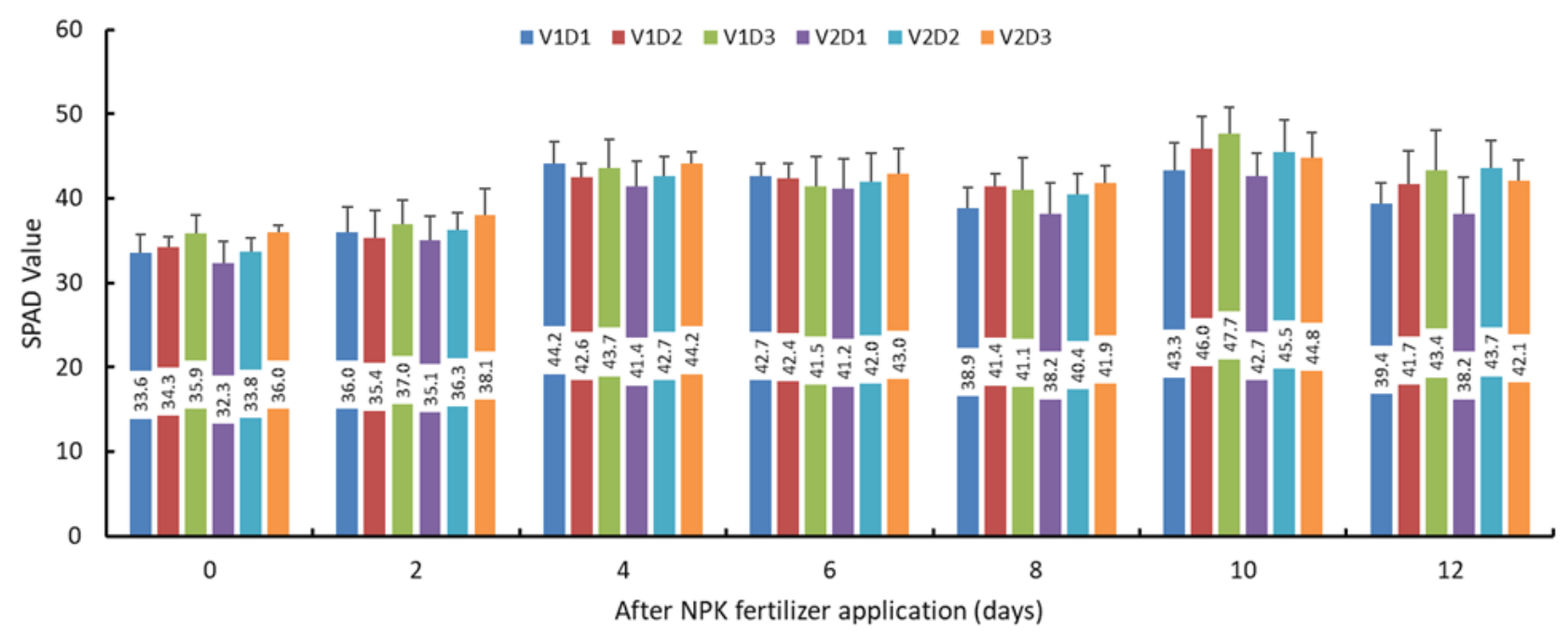

Figure 3. Response of Talinum paniculatum planted using different bottom cuts (V) and the number of leaves (D) of stem cuttings to NPK fertilizer application as indicated by the increase in SPAD value 
Single-trait and two-trait predictors were also used for developing the total area per leaf cluster estimation model in T. paniculatum. Based on the $\mathrm{R}^{2}$ value, the combination of the longest and widest leaves $\left(\mathrm{R}^{2}=0.95\right)$ was a better predictor than the separated longest leaf $\left(\mathrm{R}^{2}=0.88\right)$ and widest leaf $\left(\mathrm{R}^{2}=0.72\right)$ in each cluster. High reliability was found in both the power regression and the zero-intercept linear models if the combination of the two-trait predictor was used (Figure 7; left column). Estimation of total area per leaf cluster was more accurate $\left(\mathrm{R}^{2}=0.984\right)$ if three traits of the number of leaves $(\mathrm{NoL})$, the longest leaf, and the widest leaf in each cluster were used as a predictor, and the zero-intercept linear regression was used as the model (Figure 7; right column).

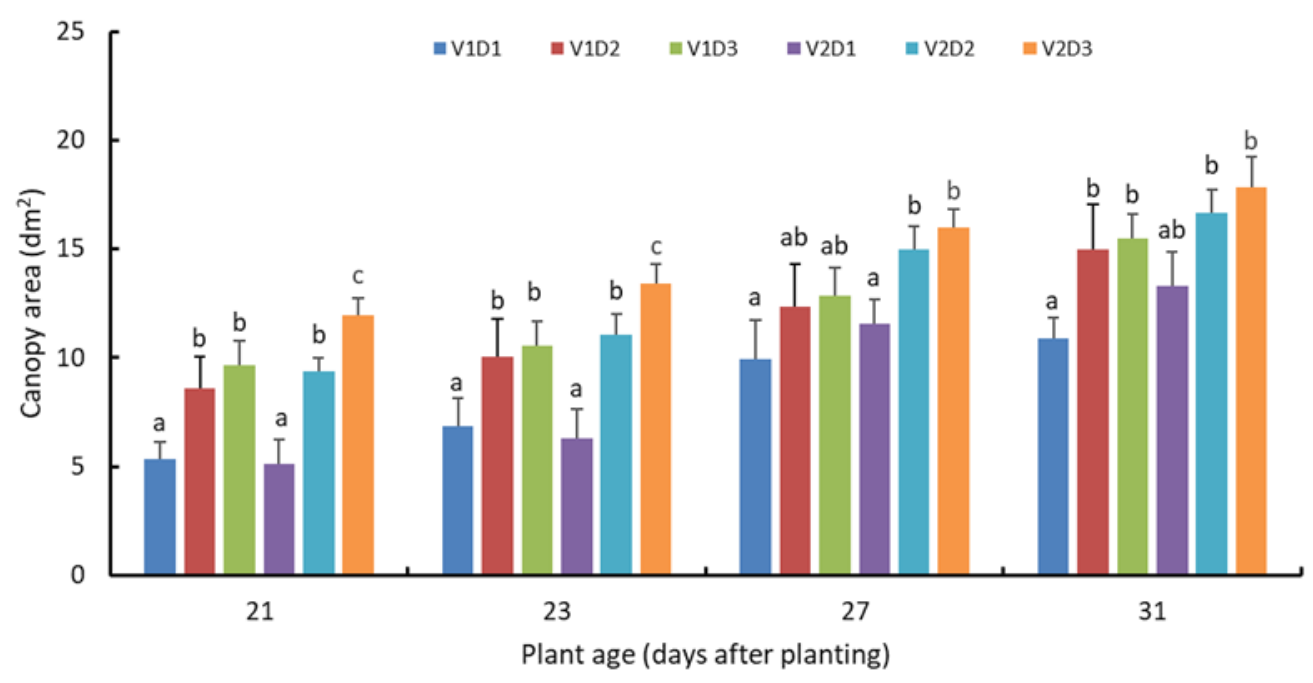

Figure 4. Canopy area in Talinum paniculatum planted using different bottom cuts (V) and the number of leaves (D) of stem cuttings at the early vegetative growth stage. V1: straight cut, V2: slanting cut, D1: stem without leaf, D2: with five leaves, and D3: with 10 leaves
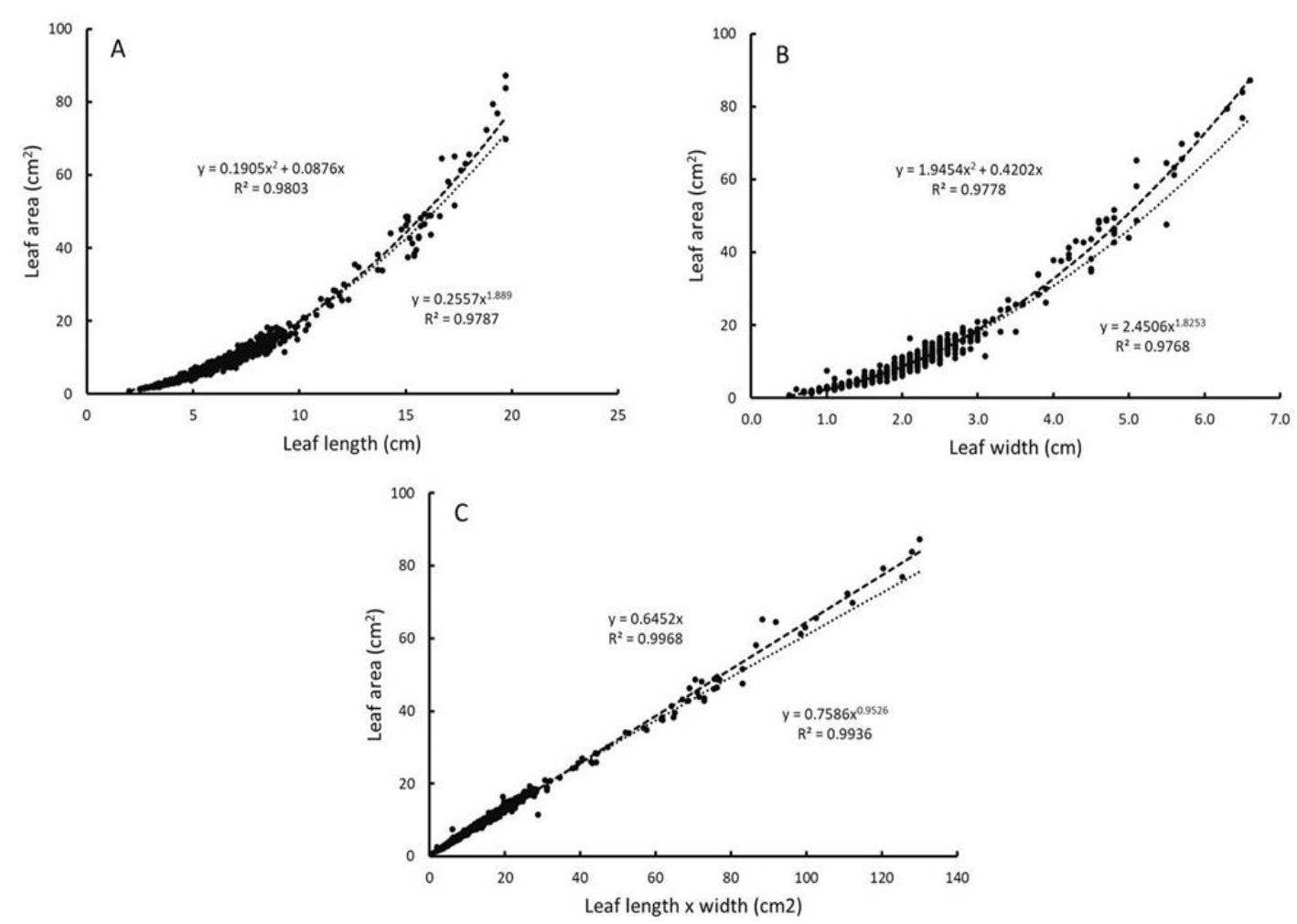

Figure 5. Accuracy between zero-intercept quadratic model (dashed line) using single trait (A and B) and zero-intercept linear model using two traits as a predictor (C) was compared to power regression model (dotted line) in estimating leaf area of Talinum paniculatum. 

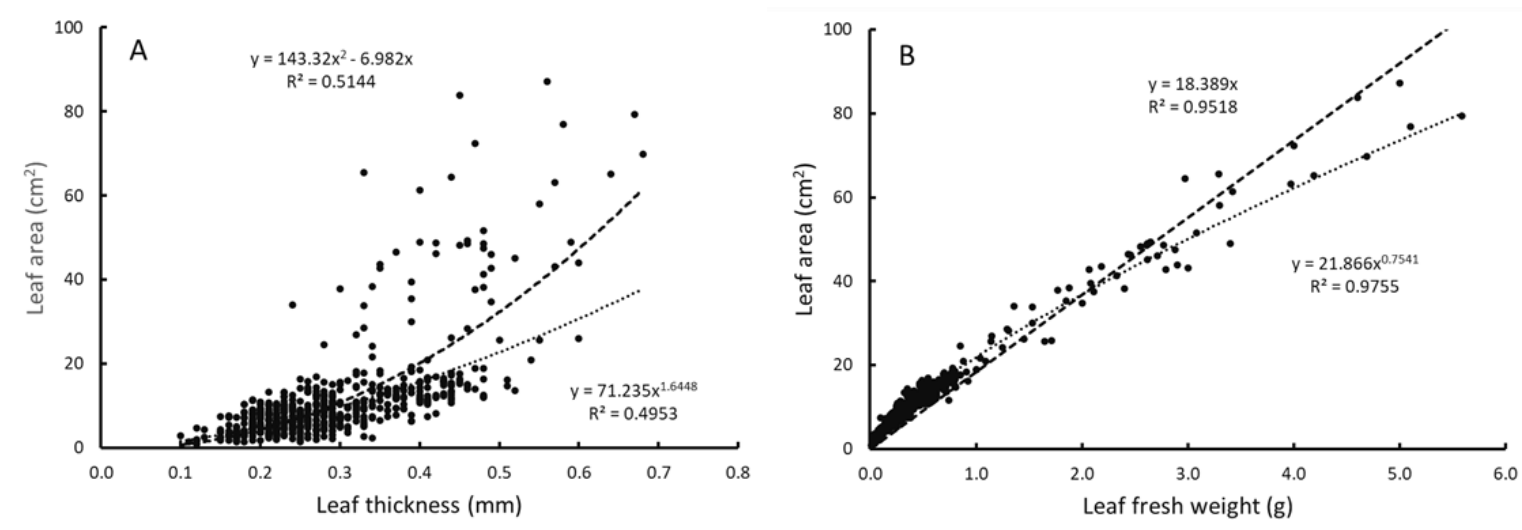

Figure 6. Comparing the accuracy of uncommon dimensional trait of leaf thickness using zero-intercept quadratic versus power model (A) and non-dimensional trait of leaf fresh weight using zero-intercept linear versus power model (B) in estimating leaf area of $T$. paniculatum. Dashed line for zero-intercept and dotted line for power models
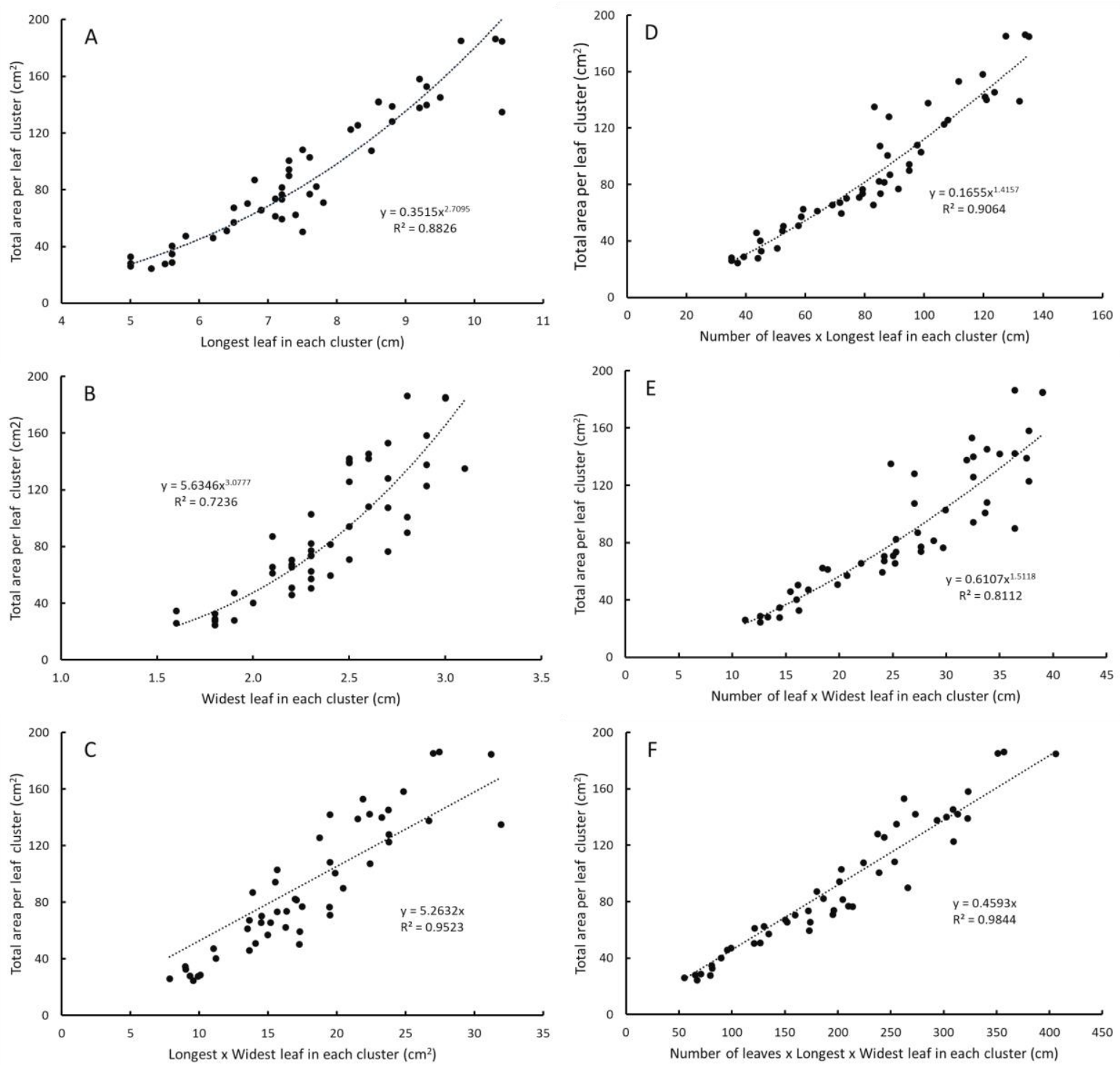

Figure 7. Left column: Estimation of the total area of each leaf cluster in the secondary branch using the longest (A), the widest (B), and combination of both traits (C). Right column: Addition of number of the leaves to the longest (D), widest (E), or combination of the two (F) as a predictor, for increasing accuracy in estimating the total leaf area of each secondary branch. Power regression models were used in A, B, D, and E panels. Zero-intercept linear regression models were used in C and F panels 

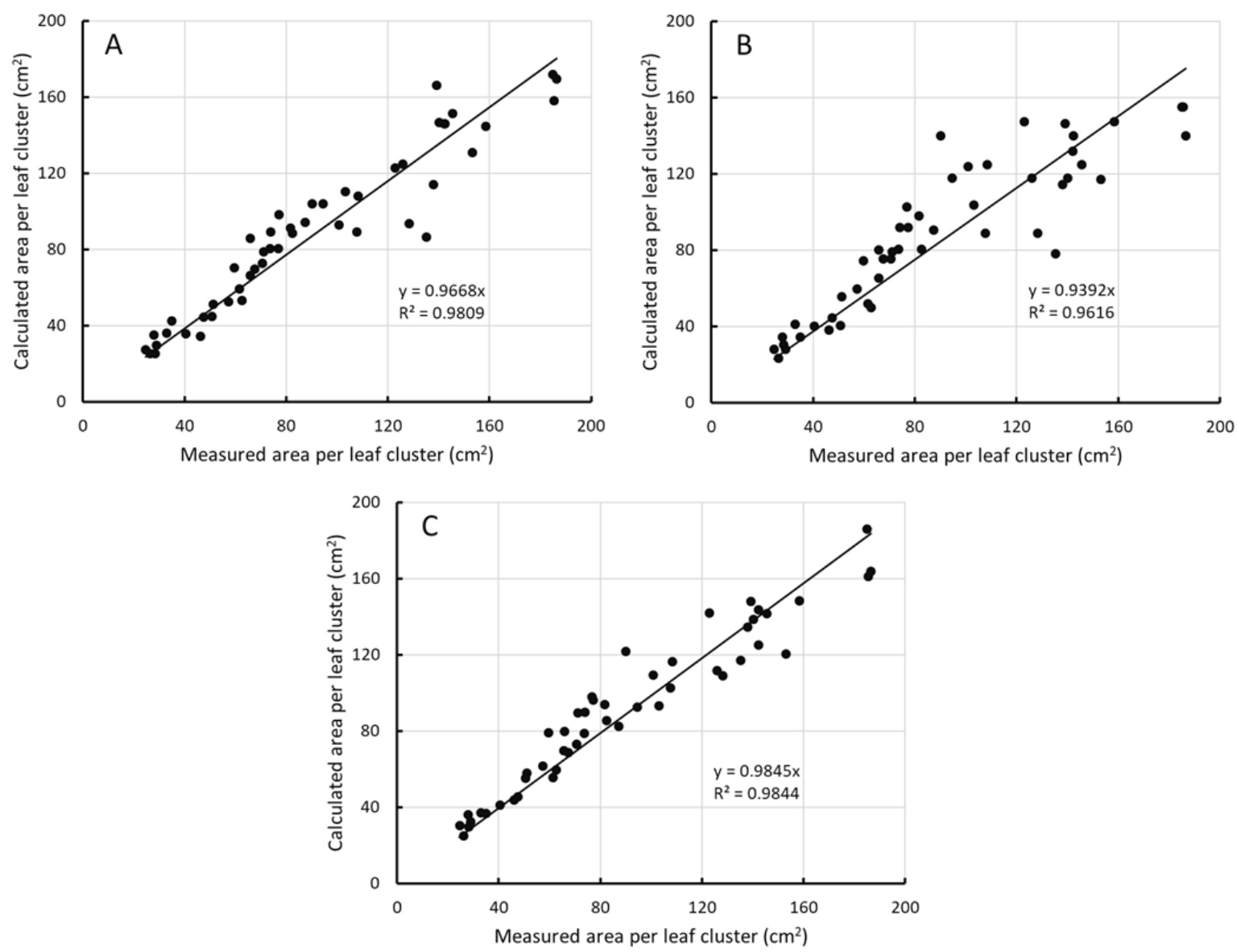

Figure 8. Reliability of the selected models for estimating total area of leaf cluster based on length (A), width (B), and length $\mathrm{x}$ width (C) of the largest leaf within each cluster

There are three complementary traits used for estimating the area of leaf within each cluster in $T$. paniculatum, i.e., length (L), width (W), and length $\mathrm{x}$ width (LW) of the largest leaf within each cluster. All developed models combined with all traits or combination of traits used as predictors have been tested for their reliability in predicting the total area of each leaf cluster, yet the only a high-performance combination of models and predictors were presented in Figure 8. The selected predictors were based on L, W, and LW of the largest leaf within each cluster. All selected models were classified as reliable models with the $\mathrm{R}^{2}=0.9809,0.9616$, and 0.9844 , for $\mathrm{L}, \mathrm{W}$, and LW, respectively.

LW was a directly related and geometrically-sound predictor since LW was an imaginary rectangular area created based on length $(\mathrm{L})$ and width $(\mathrm{W})$ of the estimated leaf (Lakitan et al. 2017). Koubouris et al. (2018) found that LA can be estimated with higher accuracy by employing $\mathrm{L}$ compared to $\mathrm{W}$ as predictor in eight olive cultivars, while Meihana et al. (2017) reported that the $\mathrm{R}^{2}$ was higher if $\mathrm{W}$ was used as a predictor instead of $\mathrm{L}$ in estimating LA in tomato.

Talinum paniculatum has been extensively used in Asian traditional medicine. Thanamool et al. (2013) reported that $T$. paniculatum is usually used as a reproductive tonic and promotes breast milk. Furthermore, Cerdeira et al. (2020) reported that T. paniculatum had been used as remedies for headache, ulcer, and diarrhea. Patel et al. (2018) revealed that $T$. paniculatum root exhibits synergistic antimicrobial activity with tetracycline, erythromycin, and streptomycin. Phytochemical investigation showed secondary metabolites contents in $T$. paniculatum, i.e, flavonoids, saponins, tannin, and other polyphenol compounds (Reis et al. 2015).

In conclusion, $T$. paniculatum grew rapidly under wet tropical conditions especially using stem cuttings propagation. The application of NPK fertilizer enhanced the growth of T. paniculatum as indicated by the increased number of branches and leaves. All L, W, and LFW were accurate predictors for single leaf area using the power regression model and LW with a zero-intercept linear regression model. An exception should be recognized that LFW data collection is destructive. Therefore, a sequential measurement on the same leaf cannot be performed. Meanwhile, an accurate and reliable model for predicting the total area per leaf cluster can be obtained using the zero-intercept linear regression model and LW traits as a predictor. If three traits are used, increased accuracy can be 
achieved by adding the number of leaves (NoL) to $\mathrm{L}$ and $\mathrm{W}$ of the largest leaf within the cluster as a compound predictor. The selected model should be a simple alternative with high reliability for shortening the observation time. This non-destructive approach can be utilized for deciding the harvesting time to obtain the optimum yield of $T$. paniculatum.

\section{ACKNOWLEDGEMENTS}

The authors are highly thankful to the editor and reviewers who provided valuable comments and suggestions to improve the quality of this article. This study was funded by Program Penelitian Unggulan Profesi, Universitas Sriwijaya, Indonesia Grant No. 0014/UN9/SK.LP2M.PT/2021.

\section{REFERENCES}

Arefin P, Habib MS, Arefin A, Arefin MS. 2021. Determination of potential sources of drug development for menstrual disorders: A qualitative analysis of published literature of in-vitro rat uterus experimental studies. Int J Pharm Chem Anal 8 (2): 45-48. DOI: 10.18231/j.ijpca.2021.010

Caplan D, Stemeroff J, Dixon M, Zheng Y. 2018. Vegetative propagation of cannabis by stem cuttings: Effects of leaf number, cutting position, rooting hormone, and leaf tip removal. Can J Plant Sci 98 (5): 11261132. DOI: $10.1139 /$ cjps-2018-0038

Cerdeira CD, Silva JJD, Netto MFR, Boriollo MFG, Moraes GOI, Santos GB, Reis LFCD, Brigagão MRPL. 2020. Talinum paniculatum: a plant with antifungal potential mitigates fluconazole-induced oxidative damage-mediated growth inhibition of Candida albicans. Rev Colomb Cienc Quím Farm 49 (2): 401-431. DOI: 10.15446/rcciquifa.v49n2.89704

Easlon HM, Bloom AJ. 2014. Easy leaf area: Automated digital image analysis for rapid and accurate measurement of leaf area. App Plant Sci 2 (7): 1-4. DOI: 10.3732/apps. 1400033

Koubouris G, Bouranis D, Vogiatzis E, Nejad AR, Giday H, Tsaniklidis G, Ligoxigakis EF, Blazakis K, Kalaitzis P, Fanourakis, D. 2018. Leaf area estimation by considering leaf dimensions in olive tree. Sci Hort 240: 440-445. DOI: 10.1016/j.scienta.2018.06.034

Kusumadewi M, Kurnia A, Permatasari R, Anggraeni S, Suharma CDN. 2011. Utilization of kolesom (Talinum paniculatum) roots enriched with ginsenoside phytochemicals by producing ready to drink beverage to overcome men sexual dysfunction. Polish J Food Nutr Sci 61: 112 .

Lakitan B, Iwanaga H, Kartika K, Kriswantoro H, Sakagami JI. 2018 Adaptability to varying water levels and responsiveness to NPK fertilizer in yellow velvetleaf plant (Limnocharis flava). Austr J Crop Sci 12 (11): 1757-1764. DOI: 10.21475/ajcs.18.12.11.p1451

Lakitan B, Kartika K, Susilawati, Wijaya A. 2021. Acclimating leaf celery plant (Apium graveolens) via bottom wet culture for increasing it adaptability to tropical riparian wetland ecosystem. Biodiversitas 22 (1): 320-328.8. DOI: 10.13057/biodiv/d220139

Lakitan B, Widuri LI, Meihana M. 2017. Simplifying procedure for a nondestructive, inexpensive, yet accurate trifoliate leaf area estimation in snap bean (Phaseolus vulgaris). J Appl Hortic 19 (1): 15-21. DOI: 10.37855/jah.2017.v19i01.03

Meihana M, Lakitan B, Susilawati, Harun MU, Widuri LI, Kartika K, Siaga E, Haris K. 2017. Steady shallow water table did not decrease leaf expansion rate, specific leaf weight, and specific leaf water content in tomato plants. Aust J Crop Sci 11 (12): 1635-1641. DOI: 10.21475/ajcs.17.11.12.pne808

Misgana Z, Daba G, Debela A. 2018. Modeling leaf area estimation for arabica coffee (Coffea arabica L.) grown at different altitudes of Mana District, Jimma Zone. Am J Plant Sci 9 (6): 1292-1304. DOI 10.4236/ajps.2018.96095
Moura IO, Santana CC, Lourenço YRF, Souza MF, Silva ARST, Dolabella S, Silva AMDOE, Oliveira TB, Duarte MC, Faraoni AS. 2021. Chemical characterization, antioxidant activity and cytotoxicity of the unconventional food plants: sweet potato (Ipomoea batatas (L.) Lam.) leaf, major Gomes (Talinum paniculatum (Jacq.) Gaertn.) and caruru (Amaranthus deflexus L.). Waste Biomass Valorization 12 (5): 2407-2431. DOI: 10.1007/s12649-020-01186-z

Nguyen TNL, Nguyen HQ, Nguyen TH., Lo TMT, Chu HM. 2018. Use of ITS DNA barcode for identification of Jewels of Opar (Talinum paniculatum) collected in Thanh Hoa, Vietnam. Vietnam J Sci Technol Eng 60 (1): 46-49. DOI: 10.31276/VJSTE.60(1).46

Nyi N, Sridokchan W, Chai-Arree W, Srinives P. 2012. Nondestructive measurement of photosynthetic pigments and nitrogen status in jatropha (Jatropha curcas L.) by chlorophyll meter. Philipp Agric Sci 95 (2): 139-145

Oluwole SO, Ogun ML, Balogun OO. 2018. Effects of different watering regimes on the growth of Talinum triangulare Jacq. (Water Leaf). J Res Rev Sci 5 (1): 14-23. DOI: 10.36108/jrrslasu/8102/50(0130)

Osathanunkul M, Madesis P. 2019. Bar-HRM: a reliable and fast method for species identification of ginseng (Panax ginseng, Panax notoginseng, Talinum paniculatum and Phytolacca americana). PeerJ 7: e7660. DOI 10.7717/peerj.7660

Patel J, Santos K, Mungai K, Arseneault V, Pokuaa YK, Louis KS, Patel K, Gilligan L, Mansour K, Patel P, Gonzalez KA. 2018. Talinum paniculatum root exhibits synergistic antimicrobial activity with tetracycline, erythromycin, and streptomycin against $S$. aureus but has no observed effect on antibiotic efficacy against E. coli. J Emerg Invest 9: 1-4.

Pezzini RV, Cargnelutti A, Alves BM, Follmann DN, Kleinpaul JA, Wartha CA, Silveira DL. 2018. Models for leaf area estimation in dwarf pigeon pea by leaf dimensions. Bragantia 77: 221-229. DOI: 10.1590/1678-4499.2017106

Proctor JTA, Sullivan AJ, Rupasinghe VPV, Jackson CJC. 2011. Morphological and ginsenoside differences among North American ginseng leaves. J Ginseng Res 35 (2): 155-161. DOI: 10.5142/jgr.2011.35.2.161

Purbajanti ED, Setyawati S, Kristanto BA. 2019. Growth, herbage yield and chemical composition of Talinum paniculatum (Jacq.). Indian J Agric Res 53 (6): 741-744. DOI: 10.18805/IJARe.A-411

Reis LFCD, 1 Cerdeira CD, Paula BFD, Silva JJAD, Coelho LFL, Silva MA, Marques VBB, Chavasco JK, Silva GAD. 2015. Chemical characterization and evaluation of antibacterial, antifungal, antimycobacterial, and cytotoxic activities of Talinum paniculatum. Rev Inst Med Trop Sao Paulo 57 (5): 397-405. DOI: 10.1590/S003646652015000500005

Saleh I, Aziz SA, Andarwulan N. 2014. Shoot production and metabolite content of waterleaf with organic fertilizer. J Agron Indones 42 (3): 210-214. DOI: 10.24831/jai.v42i3.9169

Samuel FB, Francis NA, Angwafo TE, Precillia TN. 2017. Waterleaf (Talinum triangulare) response to biochar application in a humidtropical forest soil. J Soil Sci Environ Manag 8 (5): 95-103. DOI: 10.5897/JSSEM2017.0638

Saribanon N, Utami KP, Rahayu SE. 2021. Exploration of ethnomedicinal knowledge among periurban community of Hurip Jaya Village, Babelan, District Bekasi, West Java. J Trop Biodivers 1 (2): 103-113.

Sunday E, Chukwuka C. 2016. Effect of removal of inflorescence on fresh vegetable yield in Waterleaf [Talinum triangulare (Jacq.) Willd]. IOSR J Agric Vet Sci 9 (7): 1-4. DOI: 10.9790/2380-0907010104

Teobaldelli M, Rouphael Y, Fascella G, Cristofori V, Rivera CM, Basile B. 2019. Developing an accurate and fast non-destructive single leaf area model for loquat (Eriobotrya japonica Lindl) cultivars. Plants 8 (7): 230-242. DOI: $10.3390 /$ plants8070230

Thanamool C, Papirom P, Chanlun S, Kupittayanant S. 2013. Talinum paniculatum (Jacq.) Gertn: a medicinal plant with potential estrogenic activity in ovariectomized rats. Int J Pharm Sci 5: 478-485

Toebe M, Souza RRD, Mello AC, Melo PJD, Segatto A, Castanha AC. 2019. Leaf area estimation of squash 'Brasileirinha' by leaf dimensions. Ciênc Rural 49: e20180932. DOI: 10.1590/0103$8478 \mathrm{cr} 20180932$

Tolouei SEL, Palozi RAC, Tirloni CAS, Marques AAM, Schaedler MI, Guarnier LP, Silva AO, Almeida VPD, Budel JM, Souza RIC, Santos ACD, Silva DB, Lourenço ELB, Dalsenter PR, Junior AG. 2019. Ethnopharmacological approaches to Talinum paniculatum (Jacq.) Gaertn.-Exploring cardiorenal effects from the Brazilian Cerrado. J Ethnopharmacol 238, 111873. DOI: 10.1016/j.jep.2019.111873 
Uko EA, Iren BO, Effa BE, Isong AI. 2019. Comparative efficacy of organic manures for improved performance of Waterleaf (Talinum fruticosum (L) Juss.) in the humid tropical rainforest. Int J Sci 8 (8): 1-10. DOI: $10.18483 / \mathrm{ijsci} .2126$
Widuri LI, Lakitan B, Hasmeda M, Sodikin E, Wijaya A, Meihana M, Kartika K, Siaga E. 2017. Relative leaf expansion rate and other leafrelated indicators for detection of drought stress in chili pepper (Capsicum annuиm L.). Aust J Crop Sci 11 (12): 1617-1625. DOI: 10.21475/ajcs.17.11.12.pne800 